\title{
THE IMPACT OF STRATEGIC HUMAN RESOURCE MANAGEMENT ON ENTREPRENEURIAL BEHAVIOR AMONG THE EMPLOYEES IN KUWAITI ORGANIZATIONS
}

Shaikhah J. Alainati, College of Business Studies, Department of Management, The Public Authority for Applied Education and Training (PAAET), Kuwait

Adnan A. S. Al Ali, College of Business Studies, Department of Management, The Public Authority for Applied Education and Training (PAAET), Kuwait

dx.doi.org/10.18374/JABE-21-2.4

\begin{abstract}
Entrepreneurial creativity of employees is believed to be enhancing organization value in two ways, namely, i) the quality of product-service, and ii) the quality of organization work, with rarely any additional costs. To enable such an entrepreneurial behavior among employees, this paper proposes a Creative-Staff Human Resource Allocation (CHRA) model that explains the impacts of staff training, added value, work environment, achievement, and HR practices on entrepreneurial behavior of Kuwaiti organization's employees. The model challenges the conventional notion of assigned-staff human resource allocation, which forces employees to work in silos and constraint their entrepreneurial behavior. The study has surveyed a sample of 348 respondents in Kuwait, to conclude that that value added to the staff, training, and achievement positively impact employees' entrepreneurial behavior. However, HRM practices, even though significantly impacts employees' performance, has found to be having a limited impact on employees' entrepreneurial behavior. The proposed, theoretically, and empirically based, CHRA model enhances our understanding and policy related to the designing human resource system that enable creativity and value creation.
\end{abstract}

Keywords: Entrepreneurial Creativity, Human Resource Allocation, Training, and Value. 